\title{
Detrital zircon provenances for metamorphic rocks from southern Sør Rondane Mountains, East Antarctica: A new report of Archean to Mesoproterozoic zircons
}

\author{
Ippei KITANO*, Yasuhito OsanaI $^{* *}$, Nobuhiko NAKANO ${ }^{* *}$ and Tatsuro ADACHI ${ }^{* *}$ \\ ${ }^{*}$ Graduate School of Integrated Sciences for Global Society, Kyushu University, \\ 744 Motooka, Nishi-ku, Fukuoka 819-0395, Japan \\ ${ }^{* *}$ Division of Earth Sciences, Faculty of Social and Cultural Studies, Kyushu University, \\ 744 Motooka, Nishi-ku, Fukuoka 819-0395, Japan
}

\begin{abstract}
The Sør Rondane Mountains in East Antarctica consist of the various metamorphic rocks and several plutonic rocks, which are related to formation of Gondwana supercontinent. In order to understand the detrital provenances, LA-ICP-MS zircon U-Pb dating were conducted from metamorphosed sedimentary rocks in southern Sør Rondane Mountains. Detrital cores with 990-730 Ma ages were recognized from zircons in the pelitic gneisses and calc-silicate rocks from Menipa, Imingfjella, Mefjell and Arden, while the pelitic gneiss from Tvihøgda exhibited the Archean to Mesoproterozoic ages of 2630-1060 Ma. The Neoproterozoic zircon ages are recognized not only from metamorphosed sedimentary rocks but also from metamorphosed igneous rocks distributed in the central and southern parts of the mountains. However, the Archean to Mesoproterozoic zircon ages are rare in these areas. The results imply the detrital zircons with the Neoproterozoic ages were probably derived from neighbouring igneous rocks (present metamorphosed igneous rocks), while those with Archean to Mesoproterozoic ages have clearly different provenances because of the lack in the Neoproterozoic components. This study suggests the possibility that southern Sør Rondane Mountains can be considered to be juvenile late Mesoproterozoic to Neoproterozoic terrane partly mixed with the Archean to Mesoproterozoic components.
\end{abstract}

Keywords: Detrital zircon ages, LA-ICP-MS zircon U-Pb dating, Sør Rondane Mountains, East Antarctica

\section{INTRODUCTION}

Gondwana supercontinent has mainly two tectonic models for the reconstructions with the orogenic belts defined as the East African Orogen and Kuunga Orogen (Meert, 2003) or the East Africa Antarctica Orogen (EAAO: e.g., Jacobs and Thomas, 2004) (Fig. 1). These orogenic belts along the Gondwana suture were well-constrained on the basis of the spatial distribution of metamorphic ages. Recently, the geochronological and geochemical information about pre-Gondwana periods is also important to correlate the terranes before Gondwana amalgamation and to consider how the terranes with different origins collide. For example, Jacobs et al. (2015) divided the EAAO into the Tonian oceanic arc super terrane (TAOST) with 1000-900

doi:10.2465/jmps. 151001

I. Kitano,3GS14010G@s.kyushu-u.ac.jp Corresponding author

Y. Osanai, osanai@scs.kyushu-u.ac.jp
Ma ages and Maud Belt with 1130-1040 Ma based on the geochronological, geochemical and geophysical data (Fig. 1a). Moreover, they proposed Maud Belt collided to the west and followed by the TAOST in view of the areal difference of metamorphic ages between them.

The Sør Rondane Mountains have been considered to be located within the orogenic belts during the formation of Gondwana supercontinent (Fig. 1). Therefore, the mountains would be key to provide critical constraints on the amalgamation process of the supercontinent. With this important geological background, many petrological and geochronological studies of metamorphic rocks have been conducted to reveal the metamorphic evolution in the Sør Rondane Mountains (e.g., Asami et al., 1992; Shiraishi et al., 2008; Osanai et al., 2013). However, studies focused on the protolith formation of metamorphic rocks are limited (e.g., Kamei et al., 2013). The detrital zircon ages from metamorphosed sedimentary rocks provide im- 


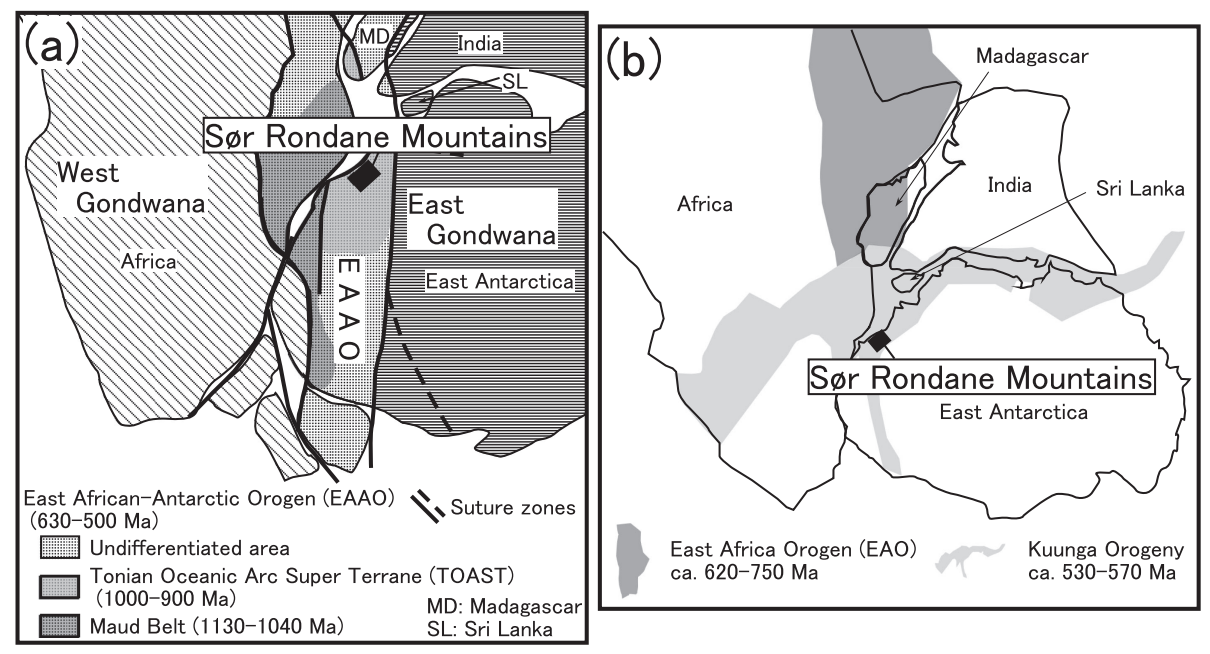

Figure 1. Simplified models of Gondwana supercontinent with the location of the Sør Rondane Mountains after Jacobs and Thomas (2004) and Jacobs et al. (2015) (a), and Meert (2003) (b). In both models the mountains are located inside orogenic belts. portant information in respect the protolith formation. The ages can be a strong tool to connect or distinguish several terranes according to the age distributions of detrital zircons (e.g., Plavsa et al., 2014), which show the geochronological characteristics of the original detrital provenance for metamorphosed sedimentary rocks. Recently, the investigations for provenance of metamorphosed sedimentary rocks in the Sør Rondane Mountains have been carried out (e.g., Osanai et al., 2013). The SHRIMP zircon $\mathrm{U}-\mathrm{Pb}$ ages from metamorphic rocks in the mountains indicated age clusters of inherited ages at $\sim 1130,1000$ and $800 \mathrm{Ma}$ with little evidence of Archean to Mesoproterozoic components (Shiraishi et al., 2008; Adachi et al., 2013). Therefore, the mountains were considered to comprise juvenile basements without old recycled materials. However, Osanai et al. (2013) reported widespread late Mesoproterozoic to Neoprtoterozoic detrital zircon ages in the mountains and identified limited distributions of Archean to early Mesoproterozoic ages in the eastern parts. However, most detrital zircon ages have been reported from the northern and eastern parts of the mountains because metamorphosed sedimentary rocks are dominant in these regions. In this study, we report zircon $\mathrm{U}-\mathrm{Pb}$ ages from metamorphosed sedimentary rocks from southern Sør Rondane Mountains to understand their detrital provenances in this area and we try to improve our understanding of the history during pre-Gondwana periods and to correlate with other Gondwana terranes on the basis of these detrital provenances.

\section{GEOLOGICAL OUTLINE}

The Sør Rondane Mountains are composed of Precambrian metamorphic rocks and various plutonic rocks intruded into the metamorphic rocks (Fig. 2a). These metamorphic rocks are divided into the Northeastern (NE) and South- western (SW) terranes by the Main Tectonic Boundary on the basis of constituent rock types, pressure-temperaturetime $(P-T-t)$ paths and detrital zircon ages (Osanai et al., 2013). The NE terrane is subdivided into units $A$ and $B$, which are mainly composed of amphibolite- and granulite-facies rocks, respectively. The SW terrane is subdivided into units $\mathrm{C}, \mathrm{D}$ and $\mathrm{D}^{\prime}$. In unit $\mathrm{C}$, granulite-facies rocks are dominant. The units $\mathrm{D}$ and $\mathrm{D}^{\prime}$ mainly consist of amphibolite- to greenschist-facies rocks. Unit $\mathrm{D}^{\prime}$ is composed of the metatonalite and separated from unit $\mathrm{D}$ by the Main Shear Zone to the north (Osanai et al., 2013) (Fig. 2). The NE terrane comprises dominant pelitic, psammitic and felsic metamorphic rocks with clockwise $P-T$ paths and Archean to Neoproterozoic detrital zircon ages with age clusters at $\sim 3260-1870,1330-780$ and $770-680 \mathrm{Ma}$, while felsic to intermediate metamorphic rocks are dominant in the SW terrane that are characterized by an anticlockwise $P-T$ paths and late Mesoproterozoic to Neoproterozoic detrital zircon ages ( 1190-950 Ma; e.g., Osanai et al., 2013). Recently, Mieth et al. (2014) reported the detailed aeromagnetic data of the Sør Rondane Mountains and proposed new division for basement rocks in the mountains (Fig. 2b). They also divided the mountains into the NE and SW terranes, and subdivided SW terrane into four subterranes: Central Sør Rondane (SR)-corridor (Eastern part of SW terrane), Western part of SW terane, trondhjemite-tonalite-granodiorite (TTG)-subterrane with high magnetic anomalies and TTG-subterrane with low magnetic anomalies (Fig. 2b). These subterranes are consistent with the dominant rock types excluding Central SR-corridor which may be related to large extensional tectonics (Mieth et al., 2014). Additionally, the protoliths of metatonalite suites in the SW terrane are considered to have formed at a juvenile oceanic arc setting at $\sim 1020$ 930 and $770 \mathrm{Ma}$ (Kamei et al., 2013; Owada et al., 2013; Elburg et al., 2015). Nakano et al. (2013) inferred mag- 


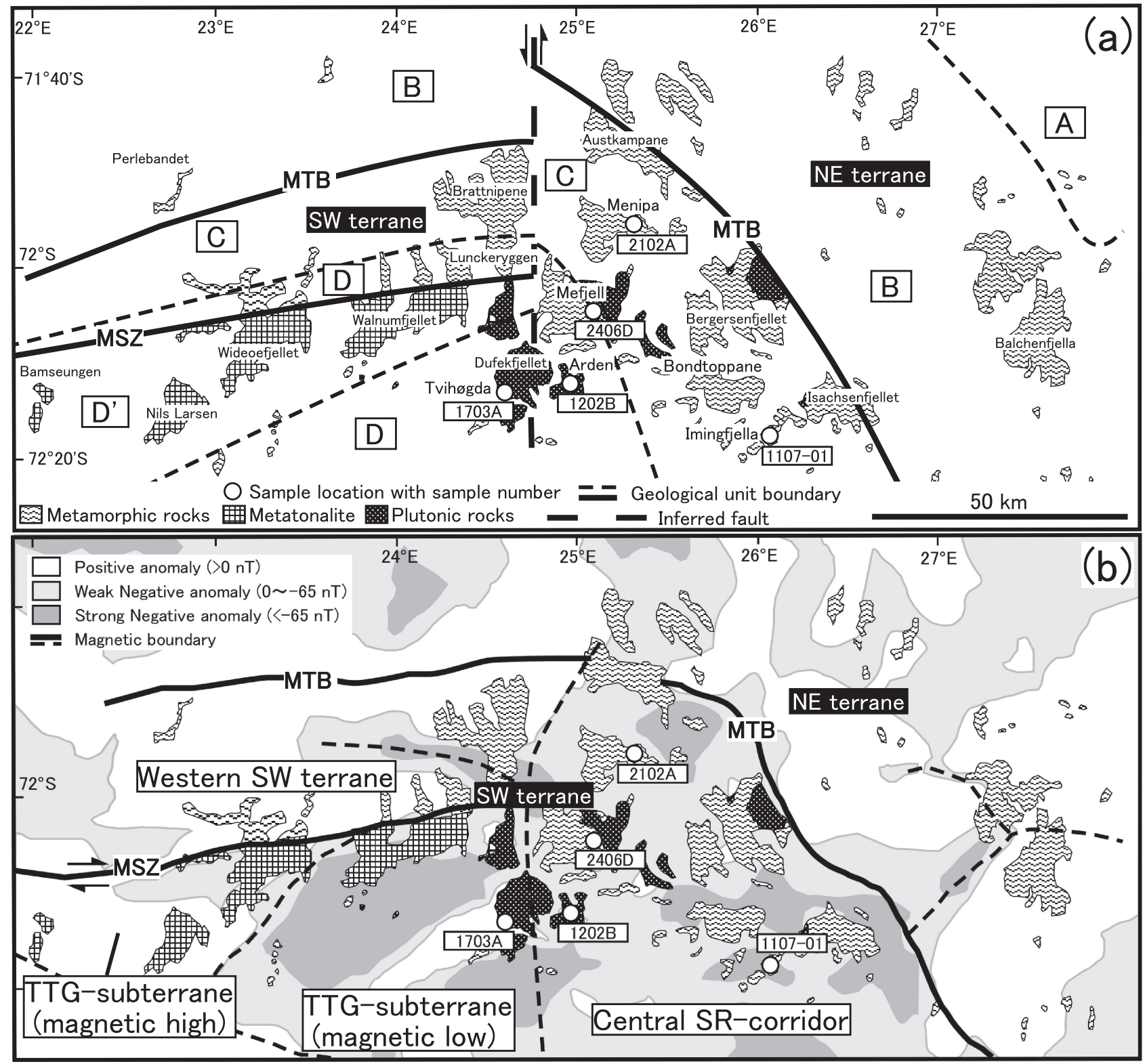

Figure 2. Simplified geological maps with geological divisions of the Sør Rondane Mountains after Osanai et al. (2013) (a) and Mieth et al. (2014) (b). (a) The mountains are divided into Northeastern (NE) and Southwestern (SW) terranes by the Main Tectonic Boundary (MTB). The NE and SW terranes are subdivided into two (units A and B) and three units (units C, D and D'), respectively (see Osanai et al., 2013). The sample locations with their sample number are also shown. (b) In the division based on the aeromagnetic data, the position of MTB is a little different from that inferred in Osanai et al. (2013). The SW terrane can be subdivided into four different magnetic domains: Central Sør Rondane (SR)-corridor (Eastern part of SW terrane), Western SW terrane, Trondhjemite-tonalite-granodiorite (TTG)-subterrane with high magnetic anomalies and TTG-subterrane with low magnetic anomalies (see Mieth et al., 2014). MSZ: Main Shear Zone.

matic activities at a continental margin setting at $\sim 1060$ and $760 \mathrm{Ma}$ from mafic and felsic gneisses in southern Austkampane. Metacarbonates from Balchenfjella, Brattnipene, Tangarden and Menipa indicate initial $\mathrm{Sr}$ isotope ratios with depositional ages of $\sim 880-790 \mathrm{Ma}$ (Otsuji et al., 2013). The granulite-facies metamorphism observed in both terranes have been considered to take place at 650 $600 \mathrm{Ma}$ and was followed by the subsequent retrograde metamorphism at 590-530 Ma (Adachi et al., 2013; Gran- tham et al., 2013; Hokada et al., 2013; Nakano et al., 2013; Osanai et al., 2013).

The studied areas (Menipa, Imingfjella, Mefjell, Arden and Tvihøgda) are located in the southern part of the Sør Rondane Mountains and belong to units C and D in the SW terrane (Fig. 2a). Geophysically, there are different magnetic affinities between Tvihøgda and other study area (Menipa, Imingfjella, Mefjell and Arden) (Fig. 2b). The dominant metamorphic rock types are felsic to inter- 

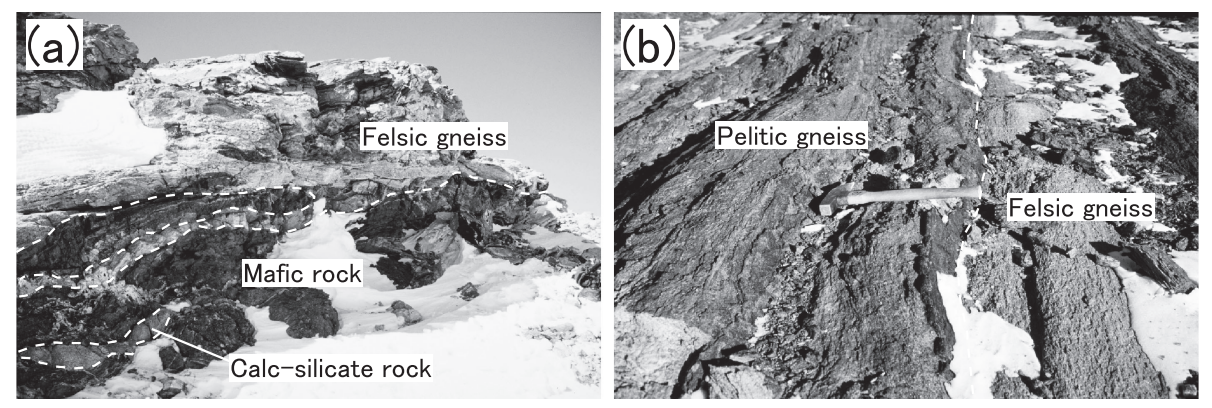

Figure 3. Modes of occurrence of the representative analysed samples. (a) Clinopyroxene-hornblende calc-silicate rock (1107-01) intercalated with felsic gneiss and mafic rock at Imingfjella. (b) Spinel, staurolite bearing garnet-biotite gneiss (2406D) interlayered with felsic gneiss at Mefjell. Color version of Figure 3 is available online from http://doi.org/10.2465/jmps. 151001 . mediate at Imingfjella, Mefjell, Arden and Tvihøgda where metamorphosed sedimentary rocks occur as layers intercalated with metamorphosed igneous rocks (Fig. 3). At Menipa, pelitic to psammitic gneisses are dominant (Ishizuka et al., 1993; Osanai et al., 1996).

\section{PETROGRAPHY}

\section{Garnet-sillimanite-biotite gneiss (2102A)}

This pelitic gneiss is collected from Menipa and is composed mainly of garnet, sillimanite, biotite, $\mathrm{K}$-feldspar, plagioclase and quartz with accessory minerals of rutile, graphite, apatite, opaque minerals, zircon and monazite. Garnet occurs as porphyroblasts (up to $5.8 \mathrm{~mm}$ in diameter) and sillimanite and biotite define gneissose fabric (Fig. 4a). Cracks in garnet porphyroblasts are filled by chlorite. Zircon grains show rounded and ovoid shapes, $0.03-0.11 \mathrm{~mm}$ long and occur in the matrix or as inclusions in garnet, biotite, plagioclase and quartz.

\section{Clinopyroxene-hornblende calc-silicate rock (1107-01)}

This calc-silicate rock collected from Imingfjella shows granoblastic textures composed mainly of clinopyroxene plagioclase, hornblende, titanite and quartz (Fig. 4b). The accessory minerals are apatite, opaque minerals and zircon. Zircon grains are euhedral and elongate, 0.03-0.14 $\mathrm{mm}$ long and occur in the matrix or as inclusions in plagioclase and quartz.

\section{Spinel, staurolite bearing garnet-biotite gneiss (2406D)}

In this pelitic gneiss from Mefjell, the main constituent minerals are garnet, biotite, $\mathrm{K}$-feldspar, plagioclase and quartz. Accessory minerals include rutile, apatite, opaque minerals, monazite and zircon. Garnet occurs as porphyroblasts (Fig. 4c; up to $9 \mathrm{~mm}$ in diameter). Biotite defines the foliation in this gneiss. Spinel, staurolite and rutile occur as inclusions in porphyroblastic garnet (Figs. 4c and $4 d$ ). Zircon grains are elongate or rounded in shape and $0.03-0.15 \mathrm{~mm}$ long, and occur in the matrix or as inclusions in biotite, plagioclase and quartz.

\section{Epidote-hornblende calc-silicate rock (1202B)}

This calc-silicate rock from Arden is composed mainly of epidote, hornblende and plagioclase with minor quartz, biotite, calcite, opaque minerals, titanite, apatite and zircon, and shows granoblastic textures (Fig. 4e). Secondary mineral is iron hydroxide, which replaces biotite. Some epidote grains form symplectites with quartz around hornblende. Zircon grains are elongated, rounded shape and $0.04-0.15 \mathrm{~mm}$ long. They are included in hornblende and plagioclase.

\section{Biotite gneiss (1703A)}

This paragneiss collected from Tvihøgda mainly consists of biotite, plagioclase, K-feldspar and quartz. The accessory minerals are apatite, rutile, opaque minerals and zircon. Biotite shows a preferred orientation (Fig. 4f). Zircon grains have various shapes such as euhedral, elongated, rounded and ovoid shapes with the length of 0.04$0.17 \mathrm{~mm}$. They occur as inclusions in biotite, plagioclase and quartz or in the matrix.

\section{LA-ICP-MS ZIRCON U-Pb DATING}

\section{Analytical method}

Zircon grains were extracted from five samples and mounted in epoxy resin, and then polished with a diamond paste by following Kitano et al. (2014a). The internal textures of zircons and their inclusions were carefully checked by cathodoluminescence (CL) image using an energy-dispersive spectroscopy-equipped scanning electron microprobe (JEOL JSM-5310S-JED2140) with a CL detector (Gatan MiniCL) housed at Kyushu University. U-Pb dating of zircons was carried out by laser ablation-inductively coupled plasma-mass spectrometry (LA-ICP-MS) using an Agilent $7500 \mathrm{cx}$ quadrupole 

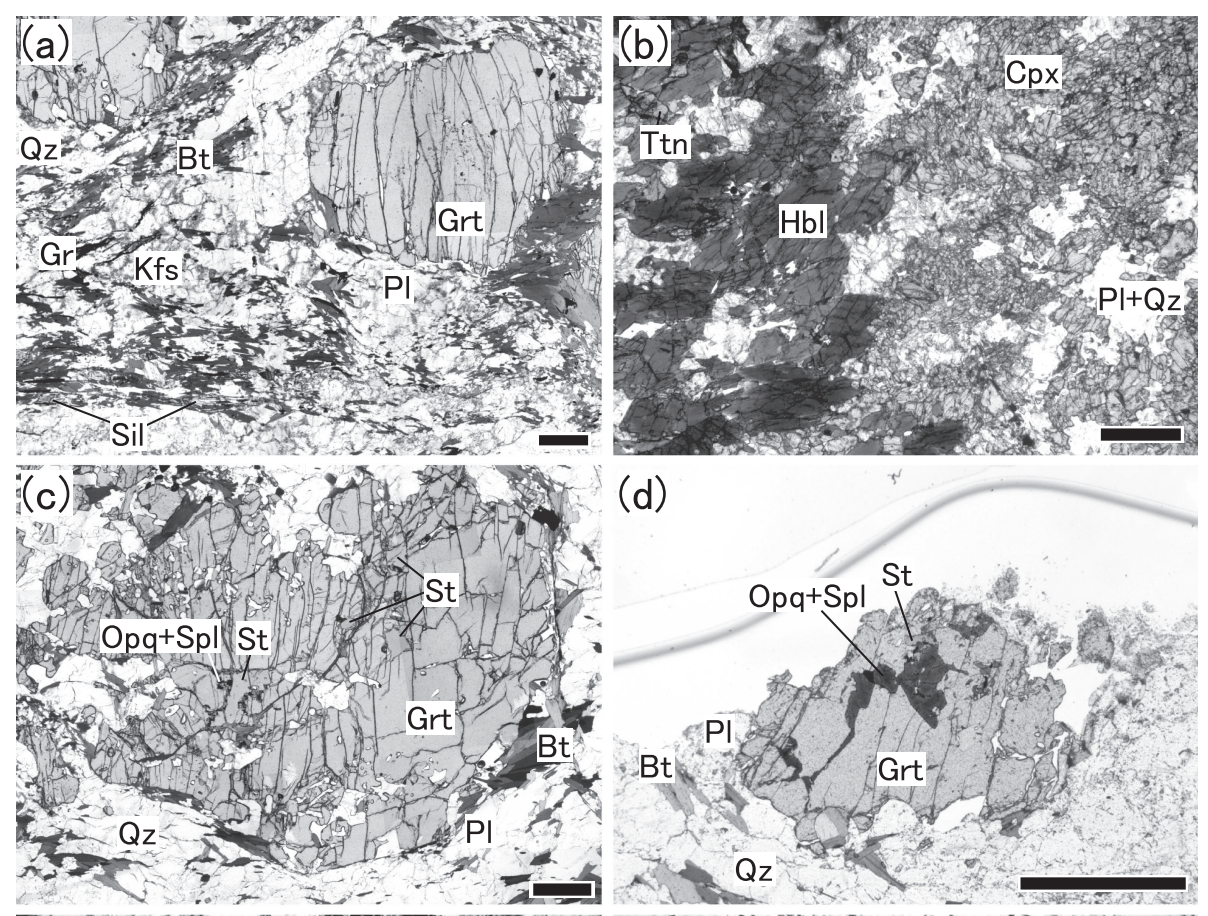

Figure 4. Photomicrographs of analysed samples. All scale bars correspond to $1 \mathrm{~mm}$. (a) Garnet-sillimanite-biotite gneiss (2102A). Porphyroblastic garnet, oriented sillimanite and biotite are recognized. (b) Clinopyroxene-hornblende calc-silicate rock (1107$01)$. This rock shows granoblastic textures. (c) and (d) Spinel, staurolite bearing garnet-biotite gneiss (2406D). Spinel and staurolite occur only as inclusions in porphyroblastic garnet. (e) Epidote-hornblende calc-silicate rock (1202B). Some epidotes replace hornblende and occur as symplectitic intergrowths with quartz. (f) Biotite gneiss (1703A). Biotite shows a preferred orientation. Color version of Figure 4 is available online from http://doi.org/10.2465/jmps. 151001.

Table 1. Summary of the results of LA-ICP-MS zircon U-Pb dating

\begin{tabular}{cccccc}
\hline \multirow{2}{*}{ Area } & Unit & Sample No. & Rock name & Zircon U-Pb age (Ma) \\
\cline { 5 - 6 } & & & Crital zircon age & Metamorphic age \\
\hline Menipa & $\mathrm{C}$ & $2102 \mathrm{~A}$ & Grt-Sil-Bt gneiss & $990,890-840$ & $640-510$ \\
Imingfjella & $\mathrm{C}$ & $1107-01$ & Cpx-Hbl calc-silicate rock & $920,800-730$ & \\
Mefjell & $\mathrm{D}$ & $2406 \mathrm{D}$ & Spl, St bg. Grt-Bt gneiss & $880,820-770$ \\
Arden & $\mathrm{D}$ & $1202 \mathrm{~B}$ & Ep-Hbl calc-silicate rock & $970-780$ \\
Tvihøgda & $\mathrm{D}$ & $1703 \mathrm{~A}$ & Bt gneiss & 2630, 2030-1850, 1530-1060 \\
\hline
\end{tabular}

ICP-MS with a New Wave Research UP-213 laser at Kyushu University. The analytical procedure is described by Adachi et al. (2012). Temora (417 Ma; Black et al., 2003) and FC-1 (1099 Ma; Paces and Miller, 1993) standards were used as calibration and accuracy checks respectively. NIST SRM-611 glass standard was used to determine the $\mathrm{Th} / \mathrm{U}$ ratio. Concordia diagrams and probability density curves were calculated using Isoplot/Ex 3.7 software (Ludwig, 2008). On concordia diagrams, data which show discordant, reverse discordant, mixed or incomplete $\mathrm{Pb}$-loss ages were excluded from interpretations of ages. Here, we considered data plotted on the concordia within error as concordant data, otherwise we did data as discordant or reverse discordant data. Dates and the isotopic ratios were calculated using GLITTER software (Griffin et al., 2008). Excluding the sample $2102 \mathrm{~A}$, overgrowth rims were too narrow to analyse. So, we could obtain the ages only from the cores. During this measurement, analysed FC-1 exhibited a weighted mean ${ }^{206} \mathrm{~Pb} /{ }^{238} \mathrm{U}$ age of $1097.7 \pm 6.6 \mathrm{Ma}(N=17, \mathrm{MSWD}=$ 

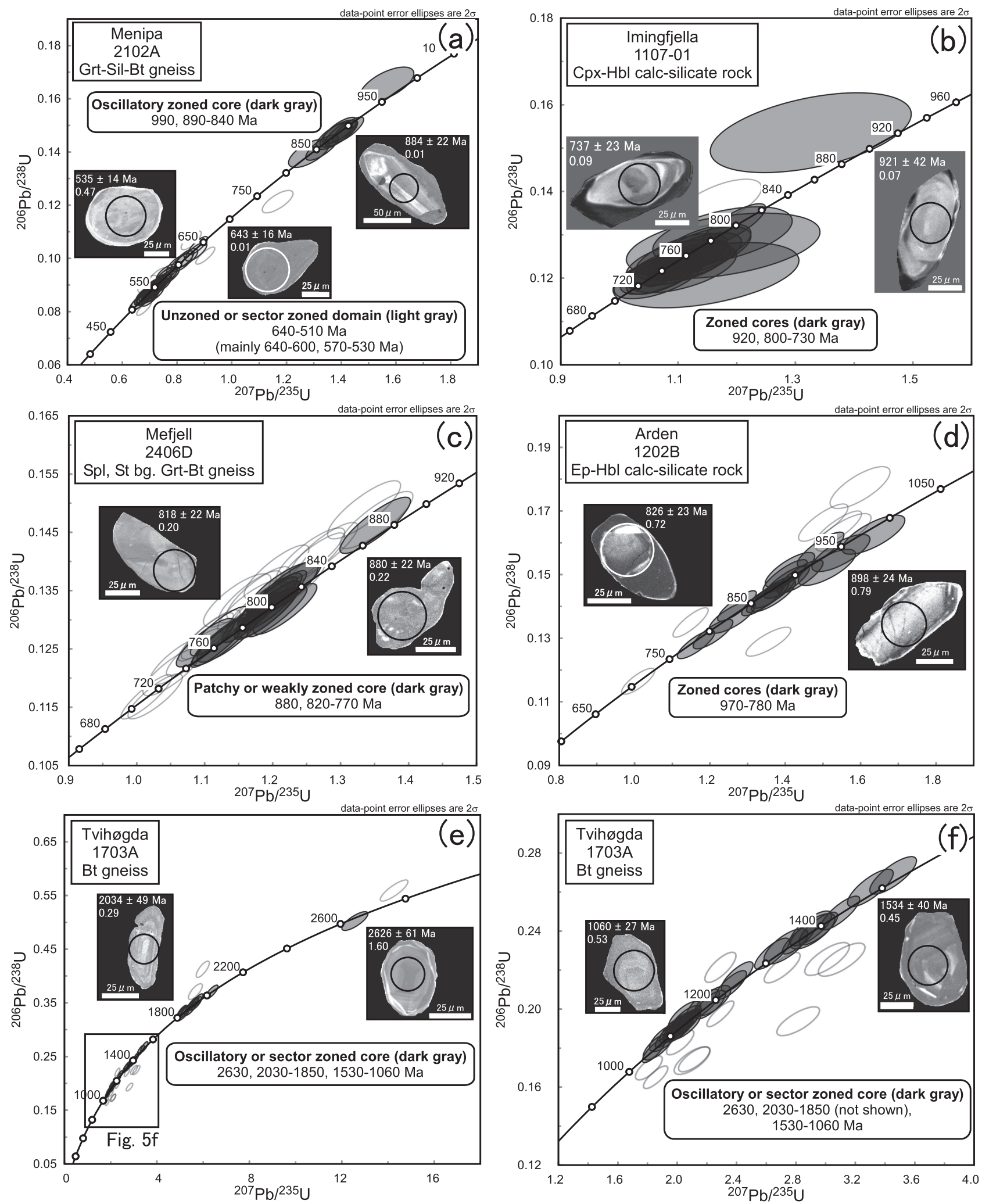

Figure 5. Concordia diagrams and the $\mathrm{CL}$ images of the analysed zircon grains with an apparent ${ }^{206} \mathrm{~Pb} /{ }^{238} \mathrm{U}$ ages and Th/U ratios. The dark and light gray ellipses are concordant data. The open ellipses are omitted data. (a) Garnet-sillimanite-biotite gneiss (2102A). (b) Clinopyroxene-hornblende calc-silicate rock (1107-01). (c) Spinel, staurolite bearing garnet-biotite gneiss (2406D). (d) Epidote-hornblende calcsilicate rock (1202B). (e) and (f) Biotite gneiss (1703A). 
0.90). The analytical results are summarized in Table 1 and listed in Appendixes 1-5 (Appendixes1-5 are available online from http://doi.org/10.2465/jmps.151001).

\section{Results}

Garnet-sillimanite-biotite gneiss (2102A). Some zircon grains exhibit oscillatory or sector zoned cores with darkCL rims, and other zircons exhibit sector zoned or unzoned dark-CL cores without overgrown rims (Fig. 5a). We analysed 51 cores and 4 rims from 52 grains and obtained 48 concordant data, of which 8 inherited cores show ${ }^{206} \mathrm{~Pb} /{ }^{238} \mathrm{U}$ ages of $\sim 990$ and $890-840$ Ma with high $\mathrm{Th} / \mathrm{U}$ ratios of $0.17-0.57$ (Fig. 5a). The data from overgrown rims and the dark-CL cores without overgrown rims scattered between $\sim 640$ and $510 \mathrm{Ma}$ and are characterized by low $\mathrm{Th} / \mathrm{U}$ ratios $(<0.08)$ (Fig. $5 \mathrm{a}$ ).

Clinopyroxene-hornblende calc-silicate rock (1107-01). Zircons show the complicated zoned cores and thin dark-CL rims (Fig. 5b). 16 cores of 16 grains were analysed and provided 15 concordant data. ${ }^{206} \mathrm{~Pb} /$ ${ }^{238} \mathrm{U}$ ages from 15 zoned cores are $\sim 920$ and $800-730$ Ma. The zoned cores have $\mathrm{Th} / \mathrm{U}$ ratios of $0.02-0.19$ and 0.64 (Fig. 5b).

Spinel, staurolite bearing garnet-biotite gneiss (2406D). Zircons have patchy or weakly zoned cores with overgrown rims (Fig. 5c). 32 cores and 5 rims from 35 grains showed 11 concordant data except some reverse discordant data and data affected by inclusions or $\mathrm{Pb}$-loss. 11 concordant data from zoned cores are concentrated in the range between $\sim 880$ and $770 \mathrm{Ma}$ with $\mathrm{Th} / \mathrm{U}$ ratios of $0.01-0.33$ (Fig. $5 \mathrm{c}$ ).

Epidote-hornblende calc-silicate rock (1202B). Zircons show various textures such as broad oscillatory, sector, patchy, weakly zoned or no zoning in the cores with thin dark-CL rims (Fig. 5d). 23 analysed points from core portions of 21 zircon grains exhibited 14 concordant data. ${ }^{206} \mathrm{~Pb} /{ }^{238} \mathrm{U}$ dates obtained from 14 cores vary from $\sim 970$ to $780 \mathrm{Ma}$ (Fig. $5 \mathrm{~d}$ ). Th/U ratios of analysed cores range from 0.07 to 1.34 .

Biotite gneiss (1703A). Zircons are mainly oscillatory or sector zoned without overgrown rims (Fig. 5e). 51 points were analysed from cores of 47 grains, resulting in 37 concordant data. Their dates are grouped at $\sim 2630 \mathrm{Ma}$ (1 point), 2030-1850 Ma (9 points) and 1530-1060 Ma (27 points) with high $\mathrm{Th} / \mathrm{U}$ ratios of $0.21-1.60$ except 0.10 (Figs. 5e and 5f).

\section{DISCUSSION}

Under the CL images, zircon grains show various shapes and internal textures in the cores. The zoned cores of their zircons exhibit scattered dates with relatively high $\mathrm{Th} / \mathrm{U}$ ratios (mostly higher than 0.10 ). These variations indicate that these zoned cores of zircons preserve inherited detrital domains. Additionally, most of these detrital zircons would be derived from igneous rocks on the basis of the zoned internal textures and high $\mathrm{Th} / \mathrm{U}$ ratios. The age distribution of detrital zircons in samples from Menipa (2102A), Imingfjella (1107-01), Mefjell (2406D) and Arden $(1202 B)$ was concentrated in the range from $\sim 990$ to 730 Ma (Fig. 6 and Table 1). This age distribution is mostly overlapped with protolith ages reported from metamorphosed igneous rocks in units $\mathrm{C}$ and D (e.g., Shiraishi et al., 2008) (Figs. 6, 7a, and 7b). It suggests the detrital zircons in metamorphosed sedimentary rocks from these nunataks may have been derived from the igneous basements (present metamorphosed igneous rocks) in units $\mathrm{C}$ and $\mathrm{D}$, as recognized from those in the central parts of the Sør Rondane Mountains (Adachi et al., 2013). Considering youngest detrital zircon age, sample from Menipa (2102A) showed $840 \mathrm{Ma}$, which corresponds well to the depositional ages of metacarbonate in Menipa (880-850 Ma: Otsuji et al., 2013). On the other

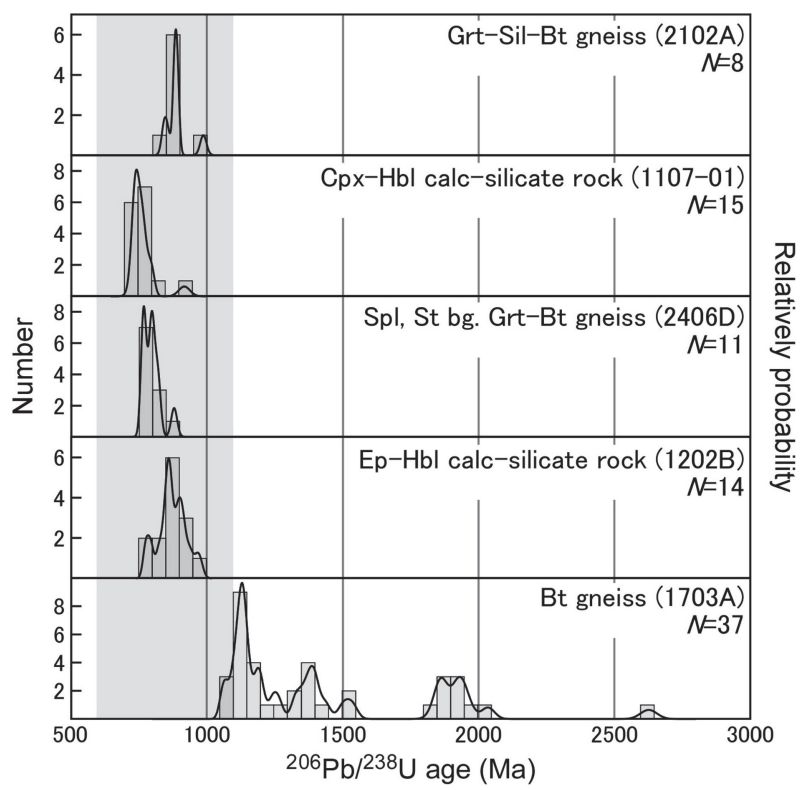

Figure 6. The histograms and probability density curves using concordant data of the detrital zircon cores obtained from garnet-sillimanite-biotite gneiss (2102A), clinopyroxene-hornblende calc-silicate rock (1107-01), spinel, staurolite bearing garnet-biotite gneiss (2406D), epidote-hornblende calc-silicate rock (1202B) and biotite gneiss (1703A). The gray field corresponds to age ranges reported from metamorphosed igneous rocks in units $\mathrm{C}$ and $\mathrm{D}$ in the SW terrane (Shiraishi et al., 2008; Adachi et al., 2013; Nakano et al., 2013; Osanai et al., 2013; Kitano et al., 2014b). Note that the detrital zircon ages in the former four samples are consistent with the protolith ages whereas the ages in biotite gneiss from the Tvihøgda are not. 


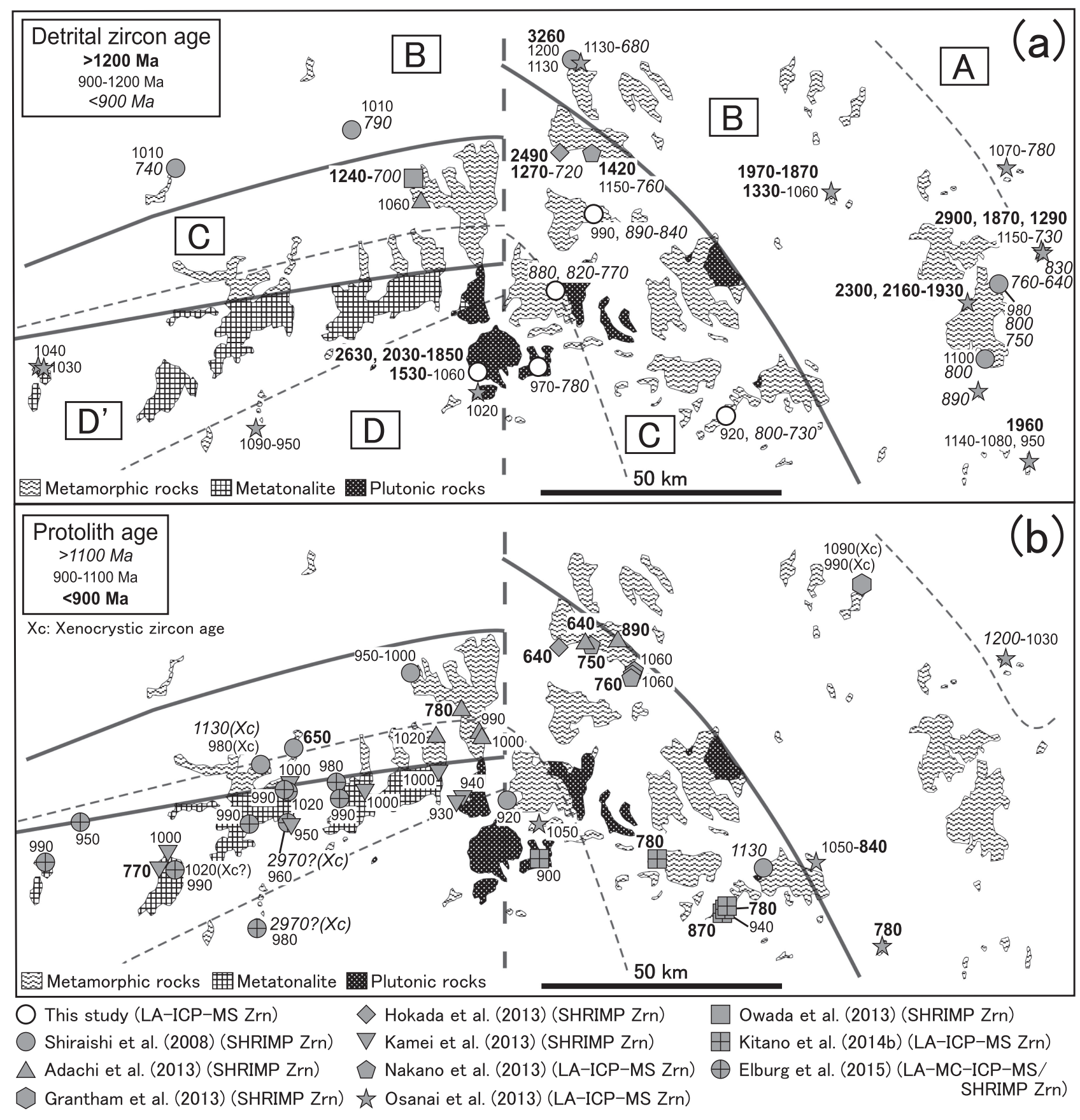

Figure 7. Compiled maps for the detrital zircon ages (a) and protolith zircon ages (b) obtained from metamorphic rocks in the Sør Rondane Mountains. The numbers are shown by million years ago (Ma). The tectonic boundaries after Osanai et al. (2013) are also shown in grey with same line symbols in Figure 2a. See legend for the source.

hand, other samples showed 780-730 Ma as youngest detrital zircon ages. These ages are consistence with youngest detrital ages reported from metamorphosed sedimentary rocks in southern Austkampane (Hokada et al., 2013; Nakano et al., 2013) and Brattnipene (Owada et al., 2013) (Fig. 7a). Therefore, the protoliths of metamorphosed sedimentary rocks at Menipa have possibly deposited earlier than those in other areas in units $\mathrm{C}$ and $\mathrm{D}$.
However, biotite gneiss from Tvihøgda (1703A) contains detrital zircons with the Archean to Mesoproterozoic ages $(\sim 2630-1060 \mathrm{Ma})$ and without any Neoproterozoic ages (Fig. 6). The late Mesoproterozoic to Neoproterozoic detrital zircon ages have been common in the SW terrane, while those older than $1200 \mathrm{Ma}$ are quite rare (Fig. 7a). It strongly suggests the origin of biotite gneiss from Tvihøgda is different from that of other met- 


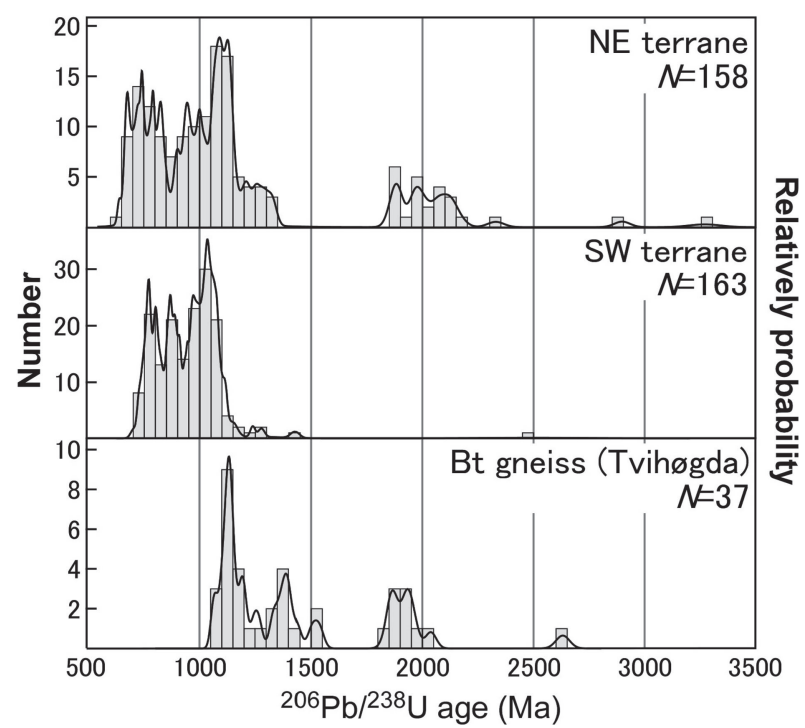

Figure 8. Compiled age distributions of detrital zircons from the NE terrane and SW terrane compared with biotite gneiss at Tvihøgda (1703A). Data sources for the NE terrane are Shiraishi et al. (2008) and Osanai et al. (2013), and those for the SW terrane are Adachi et al. (2013), Hokada et al. (2013), Nakano et al. (2013), Osanai et al. (2013), Owada et al. (2013) and this study (2102A, 1107-01, 2406D and 1202B).

amorphosed sedimentary rocks reported so far in the SW terrane (Fig. 8). Although the relation between the origin of metamorphosed sedimentary rocks and magnetic anomalies is far unknown, Mieth et al. (2014) reported the unique and strong positive magnetic anomalies from Dufekfjellet (Fig. 2b). Nevertheless, this pelitic gneiss shows greenschist- to amphibolite-facies grade with steep dips, similar to the metamorphic rocks in the southern part of unit D (e.g., Arden). It implies that the biotite gneiss (1703A) has undergone the same metamorphism and deformation to other metamorphic rocks in unit D. However, we couldn't obtain the metamorphic age from this sample because of lack of metamorphic rim in zircon. Probably, zircon in this sample couldn't grow due to the low grade metamorphism corresponding to greenschistfacies. Although the relations between rocks showing younger (Neoproterozoic) and older (Archean to Mesoproterozoic) detrital zircon ages are obscure due to the limited occurrences of metamorphosed sedimentary rocks, the similarity of the metamorphic grade suggests their precursors might be deposited at different places and were juxtaposed before metamorphism.

Archean to Neoproterozoic detrital zircon ages have been recognized widely in the NE terrane providing strong evidence of the different detrital provenances between the NE and SW terranes (Osanai et al., 2013). However, even though the SW terrane has been considered as a late Mesoproterozoic to Neoproterozoic base- ment with the juvenile affinities (e.g., Shiraishi et al., 2008), this terrane contains some Archean to Paleoproterozoic components (Fig. 8). Therefore, to identify the areal distribution of Archean to Mesoproterozoic detrital zircons in the SW terrane, further studies focusing on the older detrital zircon ages are clearly necessary. Because of less data of Archean to Mesoproterozoic detrital zircon ages from the SW terrane, the detrital provenance of these zircons is unclear. Minor detrital zircons showing Archean to Paleoproterozoic ages have been identified in metamorphic rocks from neighboring Gondwana terranes with dominant late Mesoproterozoic to Neoproterozoic ages such as the Yamato-Belgica Complex (Shiraishi et al., 1994, 2003) in East Antarctica, Alto Benfica Group (Thomas et al., 2010) and Molócuè Group (Macey et al., 2010) in Nampula Complex, all of which had been affected by the Pan-African metamorphism. Additionally, Jacobs et al. (2015) expected the existence of a crustal block at the southern end of the TOAST according to the aeromagnetic signature. These complexes or blocks may have a possibility to be related with the Archean to Mesoproterozoic fragments in the SW terrane.

\section{CONCLUDING REMARKS}

Zircon $\mathrm{U}-\mathrm{Pb}$ dating in the metamorphosed sedimentary rocks from southern Sør Rondane Mountains demonstrated inherited ages of $\sim 990-770$ Ma from pelitic gneisses and calc-silicate rocks in nunataks of Menipa, Imingfjella, Mefjell and Arden, and 2630-1060 Ma from pelitic gneiss in Tvihøgda. The former ages were mostly similar to protolith ages of metamorphosed igneous rocks from the same geological units in the mountains, whereas the latter ages are much older than these protolith ages. The results suggest that the detrital zircons in most rock types in studied area were derived from the Neoproterozoic igneous rocks, however the pelitic gneiss from Tvihøgda originally had a different provenance from them. The differences also correspond to the different magnetic affinities between Tvihøgda and other study areas. Although the studied area has been considered to have the juvenile late Mesoproterozoic to Neoproterozoic basements, we found Archean to Mesoproterozoic components. Considering the similar metamorphic grade among all analysed samples, these rocks showing different age groups might be deposited at different places and were juxtaposed before the Pan-African metamorphism.

\section{ACKNOWLEDGMENTS}

In this study, we used rock samples collected by the 31 st Japanese Antarctic Research Expedition (JARE). We 
would like to sincerely thank all members of JARE-31 and the crew of the icebreaker Shirase. Valuable discussions by the members of the JARE geology group are acknowledged. We also greatly appreciate J. Jacobs and G.H. Grantham for the constructive reviews and T. Kawakami for the editorial supports. This work was partly supported by Kyushu University doctoral course scholarship and Grants-in-Aid for Scientific Research (Nos. 21253008 and 22244063 to Y. Osanai) from the Ministry of Education, Culture, Sports, Science and Technology, Japan.

\section{DEPOSITORY MATERIALS}

Appendixes 1-5 and color version of Figures 3 and 4 are available online from http://doi.org/10.2465/jmps. 151001.

\section{REFERENCES}

Adachi, T., Osanai, Y., Nakano, N. and Owada, M. (2012) LAICP-MS U-Pb zircon and FE-EPMA U-Th-Pb monazite dating of pelitic granulites from the Mt. Ukidake area, Sefuri Mountains, northern Kyushu. The Journal of the Geological Society of Japan, 118, 39-52.

Adachi, T., Osanai, Y., Hokada, T., Nakano, N., Baba, S. and Toyoshima, T. (2013) Timing of metamorphism in the central Sør Rondane Mountains, eastern Dronning Maud Land, East Antarctica: Constrains from SHRIMP zircon and EPMA monazite dating. Precambrian Research, 234, 136-160.

Asami, M., Osanai, Y., Shiraishi, K. and Makimoto, H. (1992) Metamorphic evolution of the Sør Rondane Mountains, East Antarctica. In Recent Progress in Antarctic Earth Science (Yoshida, Y., Kaminuma, K. and Shiraishi, K. Eds.). pp. 796, Terra Scientific Publishing Company, Tokyo, 7-15.

Black, L.P., Kamo, S.L., Allen, C.M., Aleinikoff, J.N., Davis, D.W., Korsch, R.J. and Foudoulis, C. (2003) TEMORA1: a new zircon standard for Phanerozoic U-Pb geochronology. Chemical Geology, 200, 155-170.

Elburg, M., Jacobs, J., Andersen, T., Clark, C., Läufer, A., Ruppel, A., Krohne, N. and Damaske, D. (2015) Early Neoproterozoic metagabbro-tonalite-trondhjemite of Sør Rondane (East Antarctica): Implications for supercontinent assembly. Precambrian Research, 259, 189-206.

Grantham, G.H., Macey, P.H., Horie, K., Kawakami, T., Ishikawa, M., Satish-Kumar, M., Tsuchiya, N., Graser, P. and Azevedo, S. (2013) Comparison of the metamorphic history of the Monapo Complex, northern Mozambique and Balchenfjella and Austhameren areas, Sør Rondane, Antarctica: Implications for the Kuunga Orogeny and the amalgamation of $\mathrm{N}$ and $\mathrm{S}$. Gondwana. Precambrian Research, 234, 85-135.

Griffin, W.L., Powell, W.J., Pearson, N.J. and O'Reilly, S.Y. (2008) GLITTER: Data reduction software for laser ablation ICPMS. Mineralogical Association of Canada Short Course, Series 40, Appendix A2, 308-311.

Hokada, T., Horie, K., Adachi, T., Osanai, Y., Nakano, N., Baba, S. and Toyoshima, T. (2013) Unraveling the metamorphic history at the crossing of Neoproterozoic orogens, Sør Rondane
Mountains, East Antarctica: Constraints from U-Th-Pb geochronology, petrography, and REE geochemistry. Precambrian Research, 234, 183-209.

Ishizuka, H., Asami, M., Grew, E.S., Kojima, H., Makimoto, H., Moriwaki, K., Osanai, Y., Owada, M., Sakiyama, T., Shiraishi, K., Tainosho, Y., Takahashi, Y., Toyoshima, T. and Tsuchiya, N. (1993) Explanatory text of geological map of Bergersenfjella, Sør Rondane Mountains, Antarctica. Antarctic geological map series, Sheet 33, Bergersenfjella. pp. 10, National Institute of Polar Research.

Jacobs, J. and Thomas, R.J. (2004) Himalayan-type indenter-escape tectonics model for the southern part of the Neoproterozoic-early Paleozoic East African-Antarctic Orogen. Geology, 32, 721-724.

Jacobs, J., Elburg, M., Läufer, A., Kleinhanns, I.C., Henjes-Kunst, F., Estrada, S., Ruppel, A.S., Damaske, D., Montero, P. and Bea, F. (2015) Two distinct Late Mesoproterozoic/Early Neoproterozoic basement provinces in central/eastern Dronning Maud Land, East Antarctica: The missing link, 15-21 ${ }^{\circ}$ E. Precambrian Research, 265, 249-272.

Kamei, A., Horie, K., Owada, M., Yuhara, M., Nakano, N., Osanai, Y., Adachi, T., Hara, Y., Terao, M., Teuchi, S., Shimura, T., Tsukada, K., Hokada, T., Iwata, C., Shiraishi, K., Ishizuka, H. and Takahashi, Y. (2013) Late Proterozoic juvenile arc metatonalite and adakitic intrusions in the Sør Rondane Mountains, eastern Dronning Maud Land, Antarctica. Precambrian Research, 234, 47-62.

Kitano, I., Osanai, Y., Nakano, N., Adachi, T. and Yoshimoto, A. (2014a) Rapid techniques for zircon separation and the application for $\mathrm{U}-\mathrm{Pb}$ dating. Bulletin of the Graduate School of Social and Cultural Studies, Kyushu University, 20, 1-10 (in Japanese with English abstract).

Kitano, I., Osanai, Y., Nakano, N. and Adachi, T. (2014b) Bulk chemical composition and zircon $\mathrm{U}-\mathrm{Pb}$ ages for metamorphic rocks from the Sør Rondane Mountains, East Antarctica. Abstracts with Programs of Annual Meeting of Japan Association of Mineralogical Sciences, 2014, Japan Association of Mineralogical Sciences, Kumamoto, R8-P11 (in Japanese with English abstract).

Ludwig, K.R. (2008) User's Manual for Isoplot 3.70: a geochronological toolkit for Microsoft Excel. Berkeley Geochronology Center Special Publication, 4, 1-77.

Macey, P.H., Thomas, R.J., Grantham, G.H., Ingram, B.A., Jacobs, J., Armstrong, R.A., Roberts, M.P., Bingen, B., Hollick, L., De Kock, G.S., Viola, G., Bauer, W., Gonzales, E., Bjerkgård, T., Henderson, I.H.C., Sandstad, J.S., Cronwright, M.S., Harley, S., Solli, A., Nordgulen, Ø, Motuza, G., Daudi, E. and Manhica, V. (2010) Mesoproterozoic geology of the Nampula Block, northern Mozambique: Tracing fragments of Mesoproterozoic crust in the heart of Gondwana. Precambrian Research, 182, 124-148.

Meert, J.G. (2003) A synopsis of events related to the assembly of eastern Gondwana. Tectonophysics, 362, 1-40.

Mieth, M., Jacobs, J., Ruppel, A., Damaske, D., Läufer, A. and Jokat, W. (2014) New detailed aeromagnetic and geological data of eastern Dronning Maud Land: Implications for refining the tectonic and structural framework of Sør Rondane, East Antarctica. Precambrian Research, 245, 174-185.

Nakano, N., Osanai, Y., Kamei, A., Satish-Kumar, M., Adachi, T., Hokada, T., Baba, S. and Toyoshima, T. (2013) Multiple thermal events recorded in metamorphosed carbonate and associated rocks from the southern Austkampane region in the Sør 
Rondane Mountains, East Antarctica: A protracted Neoproterozoic history at the Gondwana suture zone. Precambrian Research, 234, 161-182.

Osanai, Y., Shiraishi, K., Takahashi, Y., Ishizuka, H., Moriaki, K., Tainosho, Y., Tsuchiya, N., Sakiyama, T., Toyoshima, T., Owada, M. and Kojima, H. (1996) Explanatory text of geological map of Brattnipene, Antarctica. Antarctic geological map series, Sheet 34, Brattnipene. pp. 29, National Institute of Polar Research.

Osanai, Y., Nogi, Y., Baba, S., Nakano, N., Adachi, T., Hokada, T., Toyoshima, T., Owada, M., Satish-Kumar, M., Kamei, A. and Kitano, I. (2013) Geologic evolution of the Sør Rondane Mountains, East Antarctica: Collision tectonics proposed based on metamorphic processes and magnetic anomalies Precambrian Research, 234, 8-29.

Otsuji, N., Satish-Kumar, M., Kamei, A., Tsuchiya, N., Kawakami, T., Ishikawa, M. and Grantham, G.H. (2013) Late-Tonian to early-Cryogenian apparent depositional ages for metacarbonate rocks from the Sør Rondane Mountains, East Antarctica. Precambrian Research, 234, 257-278.

Owada, M., Kamei, A., Horie, K., Shimura, T., Yuhara, M., Tsukada, K., Osanai, Y. and Baba, S. (2013) Magmatic history and evolution of continental lithosphere of the Sør Rondane Mountains, eastern Dronning Maud Land, East Antarctica. Precambrian Research, 234, 63-84.

Paces, J.B. and Miller, J.D.J. (1993) U-Pb ages of Duluth Complex and related mafic intrusions, northeastern Minnesota: geochronological insights to physical, petrogenetic, paleomagnetic, and tectonomagmatic processes associated with the $1.1 \mathrm{Ga}$ midcontinent rift system. Journal of Geophysical Research, 98, 13997-14013.
Plavsa, D., Collins, A.S., Payne, J.L., Foden, J.F., Clark, C. and Santosh, M. (2014) Detrital zircons in basement metasedimentary protoliths unveil the origins of southern India. Geological Society of America Bulletin, 126, 791-812.

Shiraishi, K., Ellis, D.J., Hiroi, Y., Fanning, C.M., Motoyoshi, Y. and Nakai, Y. (1994) Cambrian orogenic belt in East Antarctica and Sri Lanka: implications for Gondwana construction and deep crustal process. Journal of Geology, 102, 47-65.

Shiraishi, K., Hokada, T., Fanning, C.M., Misawa, K. and Motoyoshi, Y. (2003) Timing of thermal events in eastern Dronning Maud Land, East Antarctica. Polar Geoscience, 16, 76-99.

Shiraishi, K., Dunkley, D.J., Hokada, T., Fanning, C.M., Kagami, H. and Hamamoto, T. (2008) Geochronological constraints on the Late Proterozoic to Cambrian crustal evolution of eastern Dronning Maud Land, East Antarctica: a synthesis of SHRIMP U-Pb age and Nd model age data. In Geodynamic Evolution of East Antarctica: A Key to the East-West Gondwana Connection (Satish-Kumar, M., Motoyoshi, Y., Osanai, Y., Hiroi, Y. and Shiraishi, K. Eds.). pp. 456, Geological Society, London, Special Publications, 308, 21-67.

Thomas, R.J., Jacobs, J., Horstwood, M.S.A., Ueda, K., Bingen, B. and Matola, R. (2010) The Mecubúri and Alto Benfica Groups, NE Mozambique: Aids to unravelling ca. 1 and 0.5 Ga events in the East African Orogen. Precambrian Research, $178,72-90$.

Manuscript received October 1, 2015

Manuscript accepted February 3, 2016

Published online April 8, 2016

Manuscript handled by Tetsuo Kawakami, Guest Editor 